This item was submitted to Loughborough's Research Repository by the author.

Items in Figshare are protected by copyright, with all rights reserved, unless otherwise indicated.

\title{
'Executed with remarkable care and artistic feeling': popular imperialism and the music hall ballet
}

PLEASE CITE THE PUBLISHED VERSION

http://www.manchesteruniversitypress.co.uk/9780719091698/

PUBLISHER

Manchester University Press

VERSION

NA (Not Applicable or Unknown)

\section{PUBLISHER STATEMENT}

This work is made available according to the conditions of the Creative Commons Attribution-NonCommercialNoDerivatives 4.0 International (CC BY-NC-ND 4.0) licence. Full details of this licence are available at: https://creativecommons.org/licenses/by-nc-nd/4.0/

\section{LICENCE}

CC BY-NC-ND 4.0

\section{REPOSITORY RECORD}

Pritchard, Jane, and Peter Yeandle. 2019. "'executed with Remarkable Care and Artistic Feeling': Popular Imperialism and the Music Hall Ballet”. figshare. https://hdl.handle.net/2134/23832. 


\section{'Executed with remarkable care and artistic feeling': Popular Imperialism and the Music Hall Ballet.}

\section{Jane Pritchard and Peter Yeandle}

The curtain rises upon a capitally painted scene representing a naval and military port. We must pause to bestow a special word of praise upon this picture. It is executed with remarkable care and artistic feeling [...] First of all march on to the stage the British Grenadiers in their well-known costume. They are followed by the Highlanders (the Black Watch), by Irish Rifles, Royal Artillery, British sailors, and an Australian and Indian contingent, the latter being attired in the uniform of the Bengal Lancers; and we can hardly too highly praise the accuracy and attention to detail with which the uniforms of the different departments of the service have been designed [...] The banners bear the historical records of the successes of the regiments, the accoutrements are all well fitting and well made, and there is an air of "spick-and-span" smartness about the combined forces which is perfectly in harmony with the military nature of the entertainment $[\ldots][t]$ he eye was simply dazzled by a succession of brilliant uniforms [...] and the display of colour and detail was perfectly bewildering in its intricacy and brilliancy [...] the music is exactly suited to the purpose for which it is arranged.

So wrote the dramatic critic of the Era in a review of Joseph Hansen’s 'Grand Military Spectacular Ballet', Le Bivouac (Christmas, 1885), which was the first of the patriotic spectaculars to be presented at the Alhambra. Created in the aftermath of the death of General 
Gordon in Khartoum and the failure of the Sudanese campaign, Le Bivouac sought to celebrate imperial unity. The four home nations were depicted in traditional song and national dances. Dancers, representing forces from the empire, joined the throng. Further members of the corps, in the military dress of America and European nations, arrived on stage to the sound of their national music. Following re-enactments of military drills and a sham fight 'the curtain descended upon a picturesque tableau, showing Britannia enthroned, surrounded by troops'. ${ }^{1}$ The performance sold out and ran until November 1886 remaining in the critic’s eye throughout. ${ }^{2}$ In the Bell's Life in London review, 'this stirring spectacle aroused the enthusiasm of the patriotic spectators'. ${ }^{3}$ For the Times, the result was the 'stirring of the house to a fever of patriotic enthusiasm'. ${ }^{4}$

In the context of late-Victorian British imperialism, it is not surprising to find that the popular theatre reflected imperial politics and sought, in some cases, actively to engender patriotic responses. Marty Gould's research into the nineteenth-century theatre 'testifies ... to pervasiveness and popularity of imperial characters, situations, and themes in nineteenthcentury drama'. ${ }^{5}$ Edward Ziter illustrates that Victorian 'theatre was a principal space for the creation and dissemination of the modern geographic imagination'; that included careful attention to the theatrical representation of the landscapes, sounds and clothing of indigenous peoples. ${ }^{6}$ Jeffrey Richards' case study of Drury Lane, in this volume, determines similarly that the theatre reflected and responded to imperial politics. We need not list all scholarship that confirms the prevalence of imperial topics and patriotic sentiments in late-Victorian and Edwardian theatre, suffice to say that scholars have convincingly traced propagandistic influences in three of the most popular performance genres of the period: the pantomime, the music hall comedy and the melodrama. ${ }^{7}$ One aim of this chapter is to highlight the extent to which music hall ballet demands inclusion in this corpus. Balletic spectacles, such as Le 
Bivouac, have received far less attention in scholarly appraisals of the relationship between the theatrical arts and imperial culture than they merit. Le Bivouac was by no means atypical. Between 1884 and 1915, the Alhambra and Empire - the Leicester Square super-venues presented at least 140 new ballets a sizeable number of which, with explicitly patriotic intent and self-defining titles, sought to promote affection for the empire (Under One Flag (1897), Our Army and Navy (1889), Soldiers of the Queen (1900) Britannia's Realm (1902) are but a few). They all concluded with expensive military spectacles in which dancers, representing the home nations as well as the colonies, merged on stage in a climax celebrating the unity of empire. Many more ballets were presented with less telling titles yet could be inclusive of pro-imperial material. ${ }^{8}$ As the extract and reviews of the Le Bivouac demonstrate, these performances not only aimed to inculcate patriotic enthusiasm through extravagant displays of military prowess and imperial harmony, but had - in the judgements of the critics - some noteworthy success.

If we take patriotism to mean displays of affection for the nation, its monarch and its military, and imperialism - as a discursive construct embedded within, and expressed by, popular culture - as the demonstration of racial superiority, economic and technological advancement and global power, ${ }^{9}$ then it becomes clear that the ballet served a crucial purpose both as a site for the inculcation of ideology but also the performance of imperial metaphors; especially the metaphor of empire as family. ${ }^{10}$ Given the absence of the spoken word in these performances, emphasis was on visual spectacle in the form of both tableaux vivant and the carefully choreographed mass movement of casts of hundreds. The music to which the dance was set was of paramount importance. Productions aimed to arouse an emotional patriotism. That the usually restrained Times critic, in his review of Le Bivouac, used the word 'fever' is no accident; nor is the Era reviewers use of adjectives such as 'dazzling', 'bewildering' and 
'brilliant'. There is an argument to be made that ballet - because of its especial appeal to the aural and visual senses - is a particularly fecund source for research into the visceral politics of imperial performances.

This essay, moreover, demonstrates the importance of widening the geographical scope of research into dance history to include analysis of music hall ballet performed across London, not just in West End venues. This is an especially important addition to scholarship, we argue, since the ballet performed in the Canterbury, the Metropolitan and the South London halls not only played to larger audiences but sowed the seeds of what would follow in Leicester Square from the 1880s. Before analysing topical referencing in detail, therefore, the significance of music hall ballet as a site for the study of mass popular culture needs to be established.

\section{Popular ballet in nineteenth-century London}

The misleading tendency to identify the renaissance of ballet's popularity in London with the arrival of Diaghilev’s Ballet Russes in the 1910s has been corrected; so, too, has been the argument that the ballet ceased to be popular after the Romantic period. ${ }^{11}$ The very fact Victorian ballet was a form of commercially-oriented popular entertainment explains its relative absence (until recently) from mainstream historiography (the same can be said for the absence of research into pantomime’s nineteenth-century histories). ${ }^{12}$ The ballet - what became known as the 'music hall ballet' (or, retrospectively, in the words of one dance historian, 'the people's ballet') ${ }^{13}$ - was performed in giant venues to audiences of thousands. The term, although now often used in a derogatory manner, was used by the theatres themselves to describe an entertainment for a large group of artists in which dance was the substantial element. ${ }^{14}$ It was not intended as an entertainment for well-heeled clientele in well-appointed theatres. The genre was sufficiently flexible to incorporate a wide range of 
works from comic ballets, produced by itinerant groups, to lavish in-house creations drawing on a 'house' corps de ballet. On many occasions music-hall acts, knock-about comedy, monologues, acrobatics, and individual dance or skating 'turns', were worked into the presentation helping to disguise the 'plot' - crucial to ensuring the ballet did not fall foul of the 1843 Theatres Act. The significance of the 'plot'-less ballet is addressed below.

In spite of the volume of research reconstructing the social, economic and cultural histories of music hall, ${ }^{15}$ more needs to be said about the significance of ballet within the halls. ${ }^{16}$ The ballet was not mere programme filler but an entertainment in its own right; its relative relegation to decorative interlude in music hall histories belies the extent of its popularity with contemporary audiences. 'Primary sources', Carter summarises, 'are unanimous in suggesting that ballet was the main attraction in the programme'. ${ }^{17}$ It dominated programmes in Leicester Square venues: the Alhambra’s capacity was 2,336 (following the theatre's re-orientation as a music hall in 1884); the Empire's 1,726. Both venues often sold out. ${ }^{18}$ Ballet was mass produced, and commercial in orientation, but that did not prohibit critics from celebrating its inherent beauty and artfulness. Nor was its appeal to the popular understood to have devalued its contribution to Victorian visual arts; indeed, its meticulous attention to set painting and costume was often lauded. ${ }^{19}$ Productions would often be performed six times a week and would run for several months, some of the most popular for up to a year. The ballet, then, mattered not only to audiences who kept returning but also to proprietors who made a lot of money as a result of its popularity.

Analysis of West End venues is important but so too is acknowledgement, absent in much of the extant literature, ${ }^{20}$ of those other huge commercial theatres that attracted audiences in their thousands. Carter's topic is the ballet at the Empire and Alhambra theatres, yet to her study we must add those outer-London venues dedicated to music hall ballet, 
especially since these venues had larger capacities and drew audiences from a wider class range of spectator: the Canterbury (Lambeth, capacity of approximately 1,500), the Metropolitan (Paddington: seating capacity of over 2,000) and the South London Palace (also in Lambeth: seating capacity of around 4,000). ${ }^{21}$ Coinciding with a period of increased urbanisation, population swell and the attendant rise in opportunities for leisure activities, vast music halls were erected in the 1860s. The Metropolitan (opened 1864) and South London Palace (re-opened 1869) were examples of the venues which Thomas Anstey Guthrie later described in Harper's Magazine as 'large bourgeois music halls of the less fashionable parts’ of London that attracted local audiences. ${ }^{22}$ Both the Metropolitan and the South London regularly advertised in the theatrical and national press, privileging a place for dance in their productions, which explains the venues' increased popularity with the usual WestEnd set. ${ }^{23}$ The Alhambra had gained a full theatrical licence in 1871; however, becoming a legitimate theatre changed the Alhambra's profile as a venue for dance and outer-London venues quickly stepped in to claim dancers and choreographers. It was from the outer-London venues in the 1870s that the balletic spectaculars of the fin-de-siècle West End evolved. It was the outer London venues which introduced from the 1870s topicality and spectacle to music hall ballet - especially commentary on foreign policy and imperial affairs. This was a mode of topical referencing later adopted by the Alhambra, which reopened as a music hall in 1884 (after a devastating fire had required major refurbishment), and the Empire which, having opened its doors for the first time in the same year was licensed as a Palace of Variety three years later. This was the origin of a mode of political commentary later given voice in the lyrics of music hall songs. ${ }^{24}$

As a result of the 1843 Theatres Regulation Act music halls were prevented from presenting narrative works described as ballet d'action. Clause XXIII of the Act defined a stage play as a 'Tragedy, Comedy, Farce, Opera, Burletta, Interlude, Melodrama, Pantomime, 
or other Entertainment of the Stage'. ${ }^{25}$ Ballets were not singled out for specific mention, but as Albert Strong emphasised in a treatise on the relationship between the performing arts and the legal system of 1901, they would be understood to be included in 'other Entertainment':

It has been decided in a court of law that there is a difference between a ballet divertissement and a ballet d'action in a music hall. The former has no story, but merely consists of poses and evolutions by a number of elegant ladies. The ballet d'action has a regular dramatic story, and probably comes within the meaning of a "stage play". 26

Thus, legally, performances of narrative ballets were restricted to theatres operating under licence from the Lord Chamberlain, and music hall managers took considerable pains to keep up the illusion that, while there was evidently subject matter in their presentations, there was no story. This restriction made it impossible for producers to import ballet d'action from Europe which enabled theatrical space for the presentation of British topical issues. However, music hall ballet was able to draw both from aspects of the French based post-romantic ballet (particularly for fantasy productions), but also from the Italian ballo grande (literally grand ballet). The ballo grande was of especial importance since it drew from dramatic music and explosive movement and lent itself to nationalist bombast. The phenomenon that was Excelsior, for instance, debuted in London in May 1885 at Her Majesty’s to serious critical acclaim: its eleven scenes included dances illustrating the development of the transatlantic telegraph and the building of the Suez Canal. In the Italian original the ballet was a celebration of international fraternity; to a London audience, however, it was also a narration of British triumph on the global stage. The ballerina, playing the role of 'Civilisation', was dressed in a tutu decorated with the Union flag. So well received was the production that 'the cheering at the end of this ballet was so persistent that there was an attempt to repeat the final movement'. ${ }^{27}$ Significantly, as music hall ballets were not subject to censorship by the Lord 
Chamberlain, it was possible to portray living figures - which, as will be seen, explains why productions were able to provide cutting-edge commentary on topical issues. Thus, prime ministers such as Benjamin Disraeli appeared to shake a leg, the Prince of Wales’ 1875 visit to India was portrayed as a travesty role, and Queen Victoria herself could be seen in her coronation robes, or alongside Britannia, at the apotheoses of ballets. Music hall ballet, therefore, was especially well situated for the performance of contemporary political issues and this is more than evident in productions' engagement with the empire.

\section{Imperialism in the music hall ballet}

The following section traces depictions of the empire in music hall ballet. Analysis confirms the importance of outer-London theatres in the evolution of ballet. It also more than justifies our argument that popular dance requires inclusion in performance histories of popular imperialism.

Jeffrey Richards’ brief analysis of patriotic ballets at the Alhambra and Empire leads to a conclusion that:

Empire was a legitimate subject for popular culture and dance ... it was in the forefront of the popular mind at the time of the great royal events, both theatres staging ballets to coincide with the Diamond Jubilee of Queen Victoria and the Coronation of King Edward VII. There are also recurrent themes: the association of Empire with progress; Empire as the logical culmination of British history; the unity of the Empire and within it the unity of the United Kingdom; the role of the army and navy in the imperial context; but also the wealth and exoticism represented by the Empire. ${ }^{28}$ 
Carter's study, similarly short (the main focus of her book is not topical referencing but the social history of the dancers and dancing), underlines that explicitly patriotic productions enacted the military, the flag, and other national symbols: the corps 'symbolised the Empire; Britain's power in the Empire and internationally; her military glory and her role as a keeper of the peace'. ${ }^{29}$ We do not aim, however, merely to echo Richards’ and Carter's findings. Detailed research into programme notes and reviews in the theatrical and national press confirms their argument. But what, in particular, did reviewers identify as the reasons for audience patriotism?

Some reviews assumed productions were of a zeitgeist and noted the ballet's flexibility in adjusting content to reflect not only up-to-date imperial developments but also to take advantage of public mood. On these interpretations, the music hall ballet was a product of the influence of imperialism on popular culture. A more complicated question arises, however, when we consider whether or not ballets were instrumental in making audiences patriotic? Witness the critical responses to Le Bivouac noted in the introduction: in the Bell's report, the audience was already patriotic whereas the The Times observed a 'stirring of the house to a fever of patriotic enthusiasm' - that is, an audience which may or not have been patriotic at the outset of the performance had, collectively, become so by its end. J.A. Hobson's argument, in his The Psychology of Jingoism (1901), that music hall was ‘a very serviceable engine for generating military passion’ appears to have significant traction. For Hobson, music halls were 'a more potent educator than the church, the school, the political meeting, or even than the press'. Yet, in Hobson's analysis, halls had contributed to the 'debasement of popular art', vulgarising the theatre in 'appealing by coarse humour or exaggerated pathos to the animals lusts of an audience stimulated by alcohol into appreciative hilarity'. ${ }^{30}$ The ballet, in contrast to the insalubrious reputation of the halls, was often praised for its artistry. Does analysis of the operation in tandem of the sister arts - of set painting, 
costume design, and music, and their confluence within the dance - suggest a different type of emotional appeal than those direct entreaties to the cruder aspects of the human character identified by Hobson?

Evidence suggests reviewers thought it did - though some, as will be seen, acknowledged the beauty of productions whilst pointing out when they thought patriotic intent had become too crude. Several reviews used the words 'fever' and 'frantic', and all measured audience satisfaction by the extent of its 'enthusiasm'. The implication was that the collective audience response to performances was greater - like depictions of imperial harmony within the final scenes - than the sum of its individual parts. We explore this issue below in analysis of productions staged when patriotism was arguably at its peak: the Diamond Jubilee of 1897 and the second Anglo-Boer War (1899-1902).

\section{Topical referencing}

Although our focus in this chapter is the ballet's engagement with, and articulation of, an imperial culture, it must be kept in mind that ballets made topical reference to other pressing issues, especially - and not surprising given that dancing, for the female members of the corps, was precarious employment - poverty and women’s suffrage. Life (Metropolitan, 1875) displayed 'dregs of the gutter, the outcasts, the pariahs of a wealthy city, the houseless, homeless, starving, embodiments of wretchedness, the shoeblacks, the match sellers, et id genus omnes'. ${ }^{31}$ Dolly (Empire, 1890) contrasted scenes set in the homes of the virtuous poor and the selfish rich. A Dream of Wealth (Empire, 1889) was based on A Christmas Carol. Ballets were also performed in fundraising matinees; La Danse (Empire, 1896) was presented in order to raise money for clothes for impoverished children in the Board Schools. Although few productions explicitly took the suffrage movement as a central topic, with the exception perhaps of On the Heath (Alhambra, 1909), issues central to the campaign featured in a large 
number of ballets. The Revolt of the Daughters (Alhambra, 1894) and The Milliner Duchess (Empire, 1903) featured feisty female characters representing 'New Women’. On Brighton Pier (Alhambra, 1894) featured a knickerbocker-wearing dancer in the 'Lady Cyclists Galop' scene.

It was not uncommon, however, as in the case of music hall treatments of Kipling's poem The Absent-Minded Beggar (1899), for empire, patriotism and fundraising for the poor to become merged. ${ }^{32}$ Arthur Sullivan converted the poem into song and it was included in the spectacular ballet, Soldiers of the Queen (Alhambra, 1900), which 'rendered the house hoarse with applause’. Kipling records that about $£ 250,000$ was raised. ${ }^{33}$ In Luiza Collier’s The Royal Russian Rink; or, John Bull in Russia (South London Palace, 1876), prominent dancer Constance Alexander played 'an English orphan selling matches'. This enabled the inclusion of the popular ‘The Cigar-light Boy’ song, which illustrated the circumstances of London’s 'street arabs' alongside comment on contemporary affairs in Bulgaria. ${ }^{34}$ Round the Town (Empire, 1892) wove its brief narrative about the hardships experienced by the labourer's wife and child with the exploits of rumbustious schoolboys and their kind-hearted teacher. However its fifth and final scene, 'The Daughters of Empire', was a pageant demonstrating the power of imperial unity. Programme notes list the procession, each country made up of its own lead dancer and corps: England, Scotland Ireland, Wales, India, Australia, Canada, Cape Colony, British Columbia, West Indies, Gibraltar, Ceylon, New Zealand, to which were added several large British cities and seaside towns, the City of London financial district and Windsor and Eton Schools. The Era stated that the ballet was received with 'frantic enthusiasm', not in the least because - one suspects - the apotheosis of the production featured a Victoria-like Britannia symbolically embracing the whole: 'when the stage is full of a bewildering galaxy of beauty, Britannia, mighty and majestic, strides to the front, and, 
clad in a cloak made of a gorgeous Union Jack, waves her commanding and protecting trident over all' ${ }^{35}$

That the review draws attention to the emotional effect of the performance on the audience is striking. Note the language: 'bewildering galaxy of beauty'; 'gorgeous'. Credit was bestowed upon Katti Lanner, ballet mistress at the Empire since 1887, for arranging beautiful and 'ingenious' dances. The Era, in addition, reserved 'special praise' for Karl Wilhelm's 'emblematic costumes [which] are fanciful, ingenious and artistic' ${ }^{36}$ The scenery is ‘entirely admirable’ (William Telbin, the famous set painter is named), especially in conjunction with the ‘clever’ painting and carpentry. Leopold Wenzel's music was 'exactly what was required'. For the reviewer, the success of the ballet, marked by the 'frantic enthusiasm' of the audience, was predicated upon each aspect of its artistic production serving its purpose. Such a structure for review of the ballet was commonplace.

\section{Queen Victoria's Diamond Jubilee}

Given the pomp surrounding Victoria's Diamond Jubilee, it is not surprising to find ballets in Leicester Square glorifying the monarch. ${ }^{37}$ Victoria and Merrie England, first performed at the end of May 1897, premiered a few weeks before the Jubilee. Under One Flag, at the Empire, was first performed the evening (21 June) before Victoria’s Jubilee procession through London. Both ballets concluded with pageants celebrating the Queen as a symbol of British and imperial unity. Both, therefore, remained true to the formula we have seen used in Le Bivouac and Round the Town. Both received plaudits. Yet, attention to their timing as well as their critical reception is indicative. Reviews of Victoria and Merrie England occupied much more page space than Under One Flag. This was probably because, at the time of the jubilee itself, all journalistic hands were on deck to report the myriad outdoor activities. Under One Flag was caught up in jubilee fever and was not spectacular enough, in the 
context of other indoor and outdoor performances and in spite of its patriotic intent, to merit especial attention. Those papers that did offer a few lines of review of the Empire ballet, however, praised its patriotism and artistry though were less likely to provide detailed explanation.

The Era review of Victoria and Merrie England testifies to the ballet's patriotic intent: the production 'appeals entirely to our patriotism, our love of the beautiful, and our delight in active and graceful movement'. ${ }^{38}$ The Daily Mail noted that the production was so successful that 'the applause was frantic at the end, and everybody was called again and again'. ${ }^{39}$ The presence of members of the Royal family in the audience may well have contributed to the fervour. ${ }^{40}$ The Times critic thought the 'dresses in the final tableau, many of them splendidly embroidered with coats of arms, are gorgeous'. ${ }^{41}$ The Liberal Daily News worried that, to some, the piece 'may smack of aggressive jingoism', but was satisfied nonetheless - largely because of its unswerving praise of Sir Arthur Sullivan conducting his first music hall ballet - that the ballet was an 'emphatic, well-won, and well-deserved success'. ${ }^{42}$ The ballet was made up of eight historical tableaux, charting Britain's rise to greatness. Its conclusion, like other patriotic ballets, was a grand homage to imperial unity: the piece was brought to a close in 'blaze of light, colour and patriotism' by dancers representing constituent nations of the United Kingdom and its colonies. Victoria and Merrie England was (this is the Era once more): 'certainly one of the most splendidly artistic achievements which have ever been made at this popular place of amusement. It is not only a beautiful and gorgeous spectacle; it is a lesson in history and historical costume, accompanied by some of the best music ever written for ballet purposes' ${ }^{43}$ The achievement of the production is credited to the combination of its patriotic intent and its artistry 
The Telegraph positioned its review in the context of the Jubilee celebrations more generally. Victoria and Merrie England was a ‘wondrous spectacle’ and ‘a splendid commencement of the rejoicings'. ${ }^{44}$ The Alhambra ballet anticipated the jubilee fever that would grip London across June. Indeed, the production continued to play to packed houses across the summer period. The Empire ballet, Under One Flag, was scheduled to coincide with the Jubilee. For the Era, the Empire - in 'ministering to the enthusiasm of the hour' had produced 'one of the most artistic things we have seen on stage for a long time'. ${ }^{45}$ Yet, as the Daily News noted, every other West End theatre was closed for the evening of the Jubilee procession (22 June) - including the Alhambra. The paper suggested that combination of extraordinarily hot weather and the 'counter-attraction of the gaily coloured streets' meant Londoners would find sufficient visual entertainment outside of the theatre. This may explain why reviews of Under One Flag are either very short, or non-existent. The Daily News has two sentences of plot summary and finishes by punning that the ballet 'worthily maintains the traditions of the Empire'. ${ }^{46}$ 'A brilliant symbolic spectacle of loyalty', claimed the Daily Mail critic (in a review spanning only a few lines), also punning that it was 'a credit to the Empire - and that means a great deal'. ${ }^{47}$ The venue's name, clearly, presented too good an opportunity to miss in reviewing a patriotic performance in the context of Jubilee fever. The Morning Post, in another very short piece, mentions of the 'lovely' costumes, 'melodious' music and 'extremely gorgeous' painting but uses more page space, in its gossip section to report how the management of the Empire theatre had offered Indian and Colonial troops free entry to the performance; as a result, the audience looked like a mirror image of the 'picturesque uniforms' and 'the colour and sentiment of the patriotic ballet'. ${ }^{48}$ The most detailed review was in the Era. By the conclusion of the ballet, "when the "National Anthem" peals from the throats of children, men, and women, and brazen instruments, the sympathetic 
audience standing, a culmination of song and spectacle is reached which is powerfully impressive'. ${ }^{49}$

Both ballets in Leicester Square reflected the patriotic impulses of the Jubilee summer. That much is clear. Victoria and Merrie England anticipated a Jubilee fever, Under One Flag was part of it. Both productions were praised for their artistry and patriotic intent. Both ballets led the audience to perform a patriotism of its own, whether through rapturous cheering or collectively singing the national anthem. The lack of coverage of Under One Flag, however, merits further investigation. In February 1897, the South London had launched its Jubilee spectacular. The Court Ball; or, God Save the Queen exhibited a thousand electrical lights (a spectacular feat) and depicted the monarch, illuminated on her throne, 'surrounded by her sons in arms from around the world'. ${ }^{50}$ It was a roaring success, one critic noting that it was 'one of the grandest sights ever witnessed upon a variety stage'. 51 Its novelty drew crowds from all London. ${ }^{52}$ The Alhambra ballet was also an unprecedented hit: contemporary dance scholar and later historian of the art, Mark Perugini, recalled it as 'a huge success ... one of the finest "patriotic" productions ever seen on the London stage'. ${ }^{53}$ Under One Flag was not reviewed negatively but, despite meeting the formula of amalgamating patriotism and art, it was not praised with the same gusto as the Alhambra production. Its lack of media attention is suggestive that - in the context of Jubilee celebrations - it was caught up in what Tori Smith describes as an oversaturation of consumer spectacle. ${ }^{54}$ London was too busy. The Times, giving over four pages on both 23 and 24 June to review not only Victoria's procession but also street decorations and fireworks, made no reviews of West End theatre in the Jubilee week. Other performance events, specially timed to coincide with the Jubilee, may well have eaten into the Empire's audience share: Sangers circus was putting on a show in honour of the Queen, for instance, and the Tivoli hosted 'a matinee of gigantic proportions ... as the tribute of the music hall 
profession to national commemoration of the Queen's Jubilee Institute for Nurses'. The Times - reporting post hoc on the 30 June - comments that over 60 acts performed to a capacity house, including much-loved veterans such as Leo Dryden, Leo Stormont and Billy Randall as well as a large number of present-day stars of the halls. ${ }^{55}$ Potential audiences, then, would most likely already have seen a Jubilee show - perhaps even the Alhambras' offering - by the time Under One Flag debuted.

The image of the monarch dominated advertising, shops transformed themselves into repositories of souvenirs and music halls invented (or re-invented) hundreds of new songs for the occasion. The forthcoming procession dictated press reporting. The Graphic, in a playful phrase, spoke of a ‘jubilousity of jubilation’; ${ }^{56}$ the Daily Mail that Londoners had 'jubilonged for the day' (with such wordplay in the air it is little surprise that reviewers punned on the Empire Theatre's name). ${ }^{57}$ Under One Flag was a spectacle - to be sure - but in a context of heightened sensation and an assemblage of media and commercial entertainment, it was not spectacular enough to merit especial attention. It had merely moved with the times, not stood out from them. The Court Ball and Victoria and Merrie England could be sensations because they were performed in advance of the actual Queen's appearance. We might speculate that they had helped visually to prepare the crowd for seeing the Jubilee. By the time of Under One Flag's debut, the metropolis had been transformed into a giant viewing platform with miles of stands to seat an approximated 25,000 people constructed along the procession route to form a vast performance space in which the Queen and her entourage were the stars. ${ }^{58}$ The procession featured servicemen from the four home nations, foreign dignitaries including princes and prime ministers, representatives of British settlers and subject peoples - most noticeably a 17-stone Maori, Bornean headhunters, Rajasthani troops mounted on camels, hussars from Niger and the Gold Coast and Cypriots who were hissed because their fezzes meant some in the crowd confused them for Turks. One half of the procession was led by 
Frederick Roberts, no longer merely an Earl heroised in popular culture for his military exploits in Afghanistan, but promoted to Field Marshall. ${ }^{59}$ The procession, then, was not dissimilar in its composition to the finale scene of ballet spectaculars, only for two crucial differences: it was the real that was on display rather than the symbolic and the reality was far more spectacular than a ballet could ever have hoped to be.

\section{Ballet goes to war}

In the 1870s and early 1880s, outer-London theatres pioneered ballets which depicted warfare. Britain’s acquisition of Cyprus following the Congress of Berlin in 1878 resulted in the creation of Cyprus by Luiza Collier, for the South London, and Aphrodite by John D’Auban for the Metropolitan (the goddess was allegedly born in Cyprus). In the latter, D’Auban, himself, impersonated the prime minister, Disraeli, who fell asleep in his library and dreamed of visiting the new protectorate. The reviewer for Entr'Acte commented: 'Here he is supposed to enjoy the fulfilment of his dearest wishes and we see England's dictator shaking a loose leg among the neat and prettily dressed girls of Cyprus'. ${ }^{60}$ Collier’s Cyprus was partly an adaptation from her 'War' (the final section of The Cross and the Crescent which had played earlier) but she, too, included the figures of Victoria and Disraeli in the final tableau. Just how much either choreographer knew about Anglo-Cypriot politics is unclear as both D’Auban and Collier introduced elephants to Cyprus and D’Auban had his wife, Emma, perform with a snake. Nonetheless, that productions included comment on current affairs suggests a presumption of audience awareness. One is on more secure ground when assessing balletic responses to relations with Russia, not in the least because of the widespread popularity of G.W. Hunt's song, popularised by the Great MacDermott (G.H. Farrell), which coined the phrase 'jingoism':

We don't want to fight, but by Jingo if we do, 
We've got the ships, we've got the men, and got the money too,

We've fought the Bear before, and while we're Britons true,

The Russian's shall not have Constantinople. ${ }^{61}$

Collier's The Cross and the Crescent (Metropolitan, 1878) had been choreographed the previous year in response to the threat of Russia invading Constantinople. According to the Era, it was 'perhaps the most elaborate - and certainly it is the most beautiful - ballet ever seen at the Metropolitan'. It was the balletic equivalent to the song: Russians were 'greeted with hisses’, ‘Turkey with sympathetic cheers’, ‘enthusiasm culminating with "Rule Britannia”, ${ }^{62}$

Cabul (1882), at the Canterbury, also made comment on British ill-relations with Russia. Its subject was a celebration of the triumph of Roberts in the Second Anglo-Afghan War (1878-1880). Its finale also celebrated the proclamation of Queen Victoria as Empress of India (1876). A scene set in Khyber Pass was painted by scenic artist H. Norman and based on photographs. For the Era, the 'music is excellent' and the 'wild beauty' of the 'gorgeous' set painting 'fully appreciated': in 'beauty of colour and in graceful arrangement Cabul is everything a spectacular ballet should be'. The periodical also noted that Cabul doubled as an education piece as well as a patriotic interpretation of foreign policy:

Not only is Cabul a very magnificent spectacle, but it was also a patriotic idea to give, in this attractive manner, a representation of events and places respecting which so much interest has, and will be again, taken. Cabul has, for many years, been a frontier line for the possession of which Russia has secretly, and England openly, struggled diplomatically. ${ }^{63}$

Cabul was atypical of Lanner's output for, although she choreographed many up-to-date patriotic spectacles during her subsequent long tenure as the Empire's ballet mistress, she was 
uncomfortable staging military productions. D’Auban would go on to work as choreographer for the Gilbert and Sullivan operettas and ballets in Drury Lane pantomimes. ${ }^{64}$

A step back into the decade before the Leicester Square super-venues began to stage intentionally patriotic ballets is, thus, illustrative. A tradition had been set for the merging of mass military spectacle and topical referencing, demonstrating the fusion of patriotic ambition and sensitivity to contemporary politics. The symbiotic relationship was made increasingly explicit in the grand ballets at the Alhambra and Empire after 1884 and nowhere more so than in productions staged during the years of the second Boer War.

Simon Popple, in a study of the complex relationships between news reporting and the cult of war, argues the late-Victorian communications revolution 'allowed for a far more reactive set of cultural responses’ to war news. ${ }^{65}$ The increasingly visual culture of journalism, and speed with which images could become widely circulated - including war photography and early film as well as the illustrated press - meant the theatre became a site in competition for the commercialisation of reportage. ${ }^{66}$ The theatre not only told the news but also negotiated ways in which news was negotiated. In doing so, it drew from a range of dominant visual tropes. At Christmas, 1899, the Tivoli 'unleashed ... patriotic fervour’ by exhibiting scenes from the Cape in a panorama show. ${ }^{67}$ In the Jack and the Beanstalk pantomime at Drury Lane, Jack found himself confronting the Giant Blunder-Boer who had been made up to resemble the Boer leader Kruger. ${ }^{68}$ Photographs of Kruger had been widely printed in the press and it is no surprise that the advertising poster for Jack and the Beanstalk, in vivid colours and clearly depicting the defeated Kruger, was to be seen all over London. ${ }^{69}$ The Canterbury, producing a mixed bill for its Christmas fare, featured both a short ballet entitled Briton Against Boer which 'nightly arouses enthusiastic applause' and a song by a young lady, dressed in the colours of the Union Jack, lamenting her sweetheart who has 
volunteered to fight in the Transvaal: the fusion of the visual on display in the ballet and the sentimentality of the song merged into a patriotic politic of affect. It did not take long for jokes, subjecting the war to comedic subversion, to appear: at the Oxford, and with props, Gus Elen’s ‘Boer [Bore] of Bethnal Green’ thought the ‘Orange Tree State’ was a desirable colonial acquisition for 'the growth of its succulent fruit' ${ }^{70}$

Marty Gould notes that plays, required to negotiate the dilemmas posed by the ethics of a war against white, European settlers - it was much easier to narrate dramas in which the enemy was a black colonial subject - were set the task of 'marshalling public sentiment in support of the conflict'. ${ }^{71}$ Not all productions were successful since, as Popple’s evidence demonstrates, the press was often a source of criticism: not necessarily pro-Boer, but certainly critical of the effects of the crude jingoism that those displaying film, panorama or music hall skit sought to engender. ${ }^{72}$ Anxiety about the war is evident in the mixed reviews of Alhambra and the Empire ballets; so too, again, is the fusion of patriotism and artistry.

Taking its name from the popularity of the music hall song, Soldiers of the Queen opened on 11 December 1899 at the Alhambra. It was a series of 'Military Snapshots' that, like other ballets, culminated in a grand procession of troops from across the United Kingdom and the colonies. The show ran for 43 weeks and was later revived, reworked neatly as Soldiers of the King following Victoria's death. One critic remarked that management had 'a finger on the public pulse'. ${ }^{73}$ The Era applauded the execution of the 'culminating scene of patriotism'. ${ }^{74}$ The Daily Mail critic was emphatic in his admiration. The production was a triumph because it was beautifully presented: 'the animation of the whole thing, all combine to make an exceptionally pleasing spectacle’. It was ‘a production which reflects the emotions of the moment, with all that is gloomy and sad and terrible refined away from them'. ${ }^{75}$ The Daily News commented that 'the Alhambra has entered 
heartily into the spirit of the time' and the Dramatic World that the audience 'simply screamed with delight, and cheered again and again in a frenzy of patriotism' ${ }^{76}$ Troops were invited to the Alhambra. ${ }^{77}$ So patriotic was the production, however, that the Morning Post critic, after noting that 'it was heartily applauded at every opportunity', was concerned - in proto-Hobsonian fashion - that 'it is not a healthy sign that an audience should accept as patriotic a performance in which war itself is treated with the most callous levity'. Perhaps, he continued:

If the Alhambra is really bent on putting its crowd of bright, comely young damsels to patriotic uses, the best thing it can do is dazzle not us but the Boers with them by sending them out to South Africa, with instructions to get themselves captured in large numbers. ${ }^{78}$

On the one hand, this review indicates the patriotism of the production was matched by an audience already whipped up into a state of fever. On the other hand, however, the critic’s caution at the production's jingoistic ambition demonstrates a concern not only at the hall's glorification of violence at a time in which British troops were suffering terrible setbacks, but the management's commercial exploitation of the public mood. The immediacy of the ballet's reactivity to evidents is evident in an annotated programme for a performance on 1 March 1900 that reveals the relationship between patriotic display, multiple visual sources and real time news: 'News of Relief of Ladysmith received. House crowded, tremendous scenes of enthusiasm. Lady White present with Lord Lansdowne'. ${ }^{79}$ The previous day news broke that General Sir Redvers Buller had relieved the four-month siege rescuing Sir George White and his men. Lansdowne was the Secretary of State for War between 1895 and 1900. The ballet was preceded by newsreel showing jubilant scenes. 
If the Alhambra's lavish production - like its Jubilee ballet - had succeeded by both reflecting the mood of patrons but also offering spectacular fare, then the Empire's offering was less bombastic but certainly no less flexible. Round the Town Again (1899) was a reworking of Round the Town (1892) about which we have already heard. It was first presented on 8 May 1899, a few months before the Boer War had begun. Unlike the Alhambra, the Empire did not stage an explicitly patriotic spectacle - perhaps because Lanner had expressed her frustration at being required constantly to recreate military sequences. ${ }^{80}$ The ballet, like the original, represented scenes from London life. To the original, however, was added a scene in which a detachment of the $21^{\text {st }}$ Lancers returning from the Sudan were greeted by happy Londoners in front of a tableau of Charing Cross Station. It was a gesture of support for the victory campaign and reflective of up-to-date news. ${ }^{81}$ Following the outbreak of war, the ballet altered its tableau and dance: those returning from East Africa to Charing Cross were replaced by soldiers leaving the Wellington Barracks for service overseas. Round the Town Again originally featured scenes from Bond Street. That was replaced by a ball for officers in the Carlton Hotel. ${ }^{82}$ The amendment, seemingly minor, must have required huge effort and expense since it involved the painting of new scenes and alterations to costumes. According to the Daily Mail, however, the effort was entirely appreciated: "the "second edition” of "Round the Town Again” at the Empire is more vivacious than the first. The scene in front of Wellington Barracks and the muster of the troops are finely animated ... extraordinary'. ${ }^{83}$

\section{Concluding thoughts}

Ballet, therefore, was sensitive to contemporary affairs and sought to reflect patriotic fervour. It is no surprise to find that the ballets - on the evidence of reviews - tapped into the public mood. Productions were praised for their blending of artistry and appropriate patriotic intent. We have not had space in this essay to investigate the class composition of audiences or the 
history of the ballet outside of London. ${ }^{84}$ It is also regrettable that space has disallowed exploration of how gender affected the symbolic depictions of home, nation and empire - and the unity of the three in the performative juxtapositions of local and geographical spaces. What is clear is that Victoria was cast as imperial mother in these ballets and that imperial harmony was depicted as a family. If this was a common expectation of ballet, then the relative lack of interest in Under One Flag might well be explained by the actual, rather than symbolic, exhibition of Victoria at the heart of an imperial exhibition during the procession. We might also have made more of national dress and the authenticity of costumes: in addition to military uniforms, the ballet stage was graced by corps performing as Egyptian slaves, Zulu warriors, Indian Nautch girls, Chinese handmaidens and Moroccan and Spanish Gypsies. ${ }^{85}$ It is on the significance of the interplay of visual and the aural, and the significance of the ballet as a multi-sensory aspect of popular culture, that we offer with some speculative concluding thoughts.

Towards the end of the nineteenth century, music was increasingly understood as a communal cultural practice: when collectively heard, it was understood to effect a collective emotional response. ${ }^{86}$ That the quality music of was lauded by reviewers was important. Musical scores operated on two levels: to perform a variety of instantaneously recognisable national musics (note the deliberate plural); and to incorporate new melodies that would become expressive of key sensations. ${ }^{87}$ It was no accident, therefore, that ballets that depicted empire wove indigenous sounds - sometimes folk song, sometimes national anthem - into their musical narrative (to which, suitable attired chorus girls, would dance). Art, similarly, when witnessed through communal modes of seeing, could confer context-specific meaning. As Lynda Nead has argued for mid-Victorian London, the visual was a 'universal language’ and key tropes, unrecognisable to us, would likely have provided common points of identification for Victorians. ${ }^{88}$ That this universal language should translocate to the theatre is 
not a surprise. Martin Meisel does not discuss ballet in Realizations, but does - nonetheless demonstrate that stage dramas constructed sets and tableaux that signified a cultural circuit of ready identification of iconic images. ${ }^{89}$ Charing Cross station, for instance, used in Round the Town Again, evoked W.P. Friths The Railway Station (1862). Seaside ballets, such as Ramsgate! (Metropolitan, 1876) and By the Sea (Empire, 1891), reimagined Frith’s Ramsgate Sands: Life at the Seaside (1854). The artist's Derby Day (1856-8) found its way into visual representation in both Life (Metropolitan, 1875) and The Girl I Left Behind Me (Empire, 1893). While these common images might not immediately reference the empire, they do set a context for thinking about late-Victorian ways of spectating. If Meisel's formulation of the cultural crossovers of Victorian visual media is applied the very end of the Victorian period, then the foremost mode of seeing was likely also to be influenced by imperial signifiers: not just the war photograph, or the early film, or the illustrated newspaper or magazine with the specific focus on the war event, but in a vast array of consumer goods likely to be seen in the everyday life experience: toys, advertising and brand packaging, to name but a few. ${ }^{90}$ What significance, then, for thinking of the ballet as a mode of cultural visualisation that both reflected and shaped popular culture?

We might speculate, on this interpretation, that late-Victorian audiences would be able to identify common tropes of imperial representation. Far-flung adventures and wars, reported as 'facts' and disseminated in myriad images circulating freely through popular visual culture, would reduce geographical distance: both by the immediacy of reporting but also the speed with which the theatre re-told and interpreted the news as cultural event. Ballet finales, grand military spectaculars, depicted the nations of empire in a microcosm that represented - to a suitable soundtrack - the global stage; the empire as a global family. The 'illusion of reality', Edward Ziter argues, lay in audience 'knowledge that the real was mixed with the theatrical'. ${ }^{91}$ Reviewers' commentaries on the function of artistry as a crucial 
element determining the realisation of patriotic intent would suggest that the ballet served not only to heighten 'the illusion of reality' but to effect an emotional response. The music hall ballet was entertainment and education, but it was also inspiration and a site for inculcation. For this reason we believe it merits further study as a location for the representation and negotiation of popular culture in general and the politics of popular imperialism in particular.

${ }^{1}$ Era, 26 December 1885.

2 The Daily News, 21 August 1886, for instance, made much of the visit by a group of Canadian Artillery Volunteers to the Alhambra.

${ }^{3}$ Bell's Life in London, 22 December 1885.

${ }^{4}$ The Times, 25 December 1885.

${ }^{5}$ Marty Gould, Nineteenth-Century Theatre and the Imperial Encounter (London: Routledge, 2011), 9.

${ }^{6}$ Edward Ziter, The Orient on the Victorian Stage (Cambridge: Cambridge University Press, 2003), 165.

${ }^{7}$ J.M. MacKenzie, Propaganda and Empire: the manipulation of public opinion (Manchester: 1984), chapter 2: ‘The Theatre of Empire’; Jim Davis, ‘Imperial Transgressions: The Ideology of Drury Lane Pantomime in the Late Nineteenth Century', New Theatre Quarterly 12:46 (1996), 147-55; Michael Booth, 'Soldiers of the Queen: Drury Lane Imperialism', in Michael Hays and Anastasia Nikolopoulou (eds.), Melodrama: the Cultural Emergence of a Genre (Basingstoke: 1999), 3-20; Michael Pickering, Blackface Minstrelsy in Britain (Aldershot: Ashgate, 2008).

${ }^{8}$ Alexandra Carter, Dance and Dancers in Victorian and Edward Music Hall Ballet (Aldershot: Ashgate, 2005), 1-2, 20, 157-61. About half of ballets were based on fairy tales or 
constituted historical re-enactments, both genre of which Paul Readman reminds us in his analysis of pageants and other outdoor performances served as locations for civic and patriotic pride. 'The Place of the Past in English Culture, c.1890-1914', Past and Present 186 (2005), 147-99.

${ }^{9}$ Stuart Ward, ‘Echoes of Empire’, History Workshop Journal 62: 1 (2006), 264-78.

${ }^{10}$ On the ways in which imperialism became manifest in the language of popular culture, see Robert MacDonald, The Language of Imperialism: Myths and Metaphors of Popular Imperialism (Manchester: Manchester University Press, 1994) and Ansgar Nünning and Jan Rupp, 'The Dissemination of Imperialist Values in late-Victorian Literature and Other Media’, in Astrid Erll, Herbert Grabes and Ansgar Nünning (eds), Ethics in Culture: the Dissemination of Values through Literature and other Media (New York: Walter de Gruyter, 2008), 255-78.

${ }^{11}$ Amy Koritz, for instance, regularly uses the word 'devalued' to describe music hall dances. 'Moving Violations: Dance in the London Music Halls, 1890-1910', Theatre Journal 42:4 (1990), 419-31.

${ }^{12}$ Carter charts historiographical lacunae in more detail. Dance and Dancers, 8-26. See also Jane Pritchard, “"More Natural than Nature, More Artificial than Art”: the dance criticism of Arthur Symons’, Dance Research 21:2 (2003), 36-89. Anne Witchard, ““Bedraggled Ballerinas on the Bus back to Bow": The "Fairy Business”, 19: Interdisciplinary Studies in the Long Nineteenth Century 13 (2011). Available at: http://www.nineteen.bbk.ac.uk/index.php/19/article/view/618. Date accessed: 17 Sep. 2014. On pantomime, see Jim Davis (ed.), Victorian Pantomime: a collection of critical essays (Basingstoke: Palgrave, 2010); and Jeffrey Richards, The Golden Age of Pantomime: Slapstick. Spectacle and Subversion in Victorian England (London: I.B. Tauris, 2014). 
${ }^{13}$ Jane Pritchard, 'Collaborative Creations for the Alhambra and the Empire’, Dance Chronicle 24:1 (2001), 56.

${ }^{14}$ It should be noted that the term ballet is here used in its wider sense of theatrical dance rather than the specific and exclusive sense of danse d'ecole or codified academic dance for in many productions the academic ballet element was restricted to a few performers or just one dancer. Essentially, music hall ballets were works with an immediate appeal to a wide audience who enjoyed the music, spectacle, colour and dance. Occasionally the term 'modern ballet' was used by contemporaries to describe these productions. Some 'ballets' also included songs and would be worthy of a place in the discussion of the origins of musical theatre.

${ }^{15}$ See, for instance, Tracy Davis, Actresses as Working Women: their social identity in Victorian culture (London: Routledge, 1991); Joseph Donohue, Fantasies of Empire: the Empire Theatre of Varieties and the Licensing Controversy of 1894 (Iowa: University of Iowa Press, 2005); Dagmar Kift, The Victorian Music Hall: Culture, Class and Conflict (Cambridge: Cambridge University Press, 1996); and, Laurence Senelick, 'Politics as Entertainment: Victorian Music Hall Songs’, Victorian Studies 19:2 (1975), 149-80. ${ }^{16}$ Some studies of famous dancers exist that seek to locate the body of the female dancer in the context of the Victorian world view. See, for instance, Judith Walkowitz on Maud Allen, 'The "Vision of Salome”: cosmopolitanism and erotic dancing in central London, 19081918', The American Historical Review 108:2 (2003), 337-76; Cheryl Wilson, ““A Dream of Motion”: Global Dance in Victorian Literature and Culture’, Nineteenth-Century Contexts 34:4 (2012), 341-57.

${ }^{17}$ Carter, Dance and Dancers, 20. 
${ }^{18}$ Stats from the Theatre Trust website.

http://www.theatrestrust.org.uk/resources/theatres/show/3263-alhambra-theatre-london. See also Diana Howard, London Theatres and Music Halls, 1850-1950 (London: Library Association, 1970).

${ }^{19}$ Kate Newey, 'Speaking Pictures: The Victorian Stage and Visual Culture’, in A. Heinrich, K. Newey and J. Richards (eds), Ruskin, the Theatre and Visual Culture (Basingstoke: Palgrave, 2009), 1-15; Rosemary Barrow, 'Toga Plays and Tableaux Vivant: Theatre and Painting on London’s Late-Victorian and Edwardian Popular Stage', Theatre Journal 62:2 (2010), 209-226.

${ }^{20}$ Dance scholars Ivor Guest and Alexandra Carter have made music hall ballet the focus of their work, yet their research relates only to the Alhambra and the Empire. Ivor Guest, Ballet in Leicester Square: The Alhambra and Empire 1860 - 1915 (London: Dance Books, 1992); Alexandra Carter, Dance and Dancers. Jeffrey Richards’ analysis of ballet, in a chapter within his comprehensive Imperialism and Music: Britain, 1876-1953 (Manchester: Manchester University Press: 2001), is similarly restricted to the West End.

${ }^{21}$ Pritchard, ‘Collaborative Creations’, Appendix I, 76-8.

${ }^{22}$ Quoted in Benny Green, The Last Empires A Music Hall Companion (London: Pavilion, 1986), 36. If space allowed, analysis of their architecture would enable insights into the development of how audience space was arranged within halls. For instance, their buildings are good examples of the gradual morphing from the traditional mid-century 'song and supper rooms' to proscenium arch theatres with orchestra pits. Architectural developments are clearly illustrated in the South London Palace and Canterbury Hall Journal (14 October 1871). Images depict tables on the floor of the pit, with a bar clearly visible to the right of the 
stage so that the audience could still eat, drink and smoke during a performance, while the horseshoe circles show rows of tiered seats of a traditional theatre.

${ }^{23}$ In 1878, the Metropolitan proclaimed 'Seven Premiere Danseuse [sic] and fifty corps de ballet in nightly Grand Ballets’ which 'are acknowledged by Press and Public to be the most elaborate and the best appointed in London'. In the same volume, the South London announced not only a 'Magnificent Ballet every Evening' but promised ‘Fresh Novelties introduced weekly in THE BALLETS' ${ }^{23}$ The Era Almanack,

${ }^{24}$ Steve Attridge, Nationalism, Imperialism and Identity in late-Victorian Culture: civil and military worlds (Basingstoke: Palgrave, 2003), 16-43; Richards, Imperialism and Music, 32465. Dave Russell, Popular Music in England, 1840-1914 (Manchester: Manchester University Press, sec. ed., 1997), 145-69.

25 ‘Theatres Act, 1843’ reproduced in A. Strong, Dramatic and Musical Law (London: Era, 1901), 97-102. On the 1843 Act, see Katherine Newey, “"Dramatic and Musical Chit Chat”: Theatrical Writing in The Athenaeum and The Illustrated London News in 1843', Victorian Periodicals Review 23:4 (1990), 167-179; Katherine Newey, 'Reform on the London Stage' in Joanna Innes and Arthur Burns, (eds.), Rethinking the Age of Reform (Cambridge, 2003). ${ }^{26}$ Strong, Dramatic and Musical Law, 57.

${ }^{27}$ Excelsior, first performed at the Teatro alla Scala in Milan in January 1881, became an international sensation playing across continental Europe and both American continents before arriving in London. Review of London debut from the Era, 30 May 1885

${ }^{28}$ Richards, Imperialism and Music, 261.

${ }^{29}$ Carter, Dance and Dancers, 89.

${ }^{30}$ J.A. Hobson, The Psychology of Jingosim (London: Grant Richards, 1901), 2-3.

${ }^{31}$ Era, 13 January 1875. 
${ }^{32}$ On theatrical fundraising more generally, see Catherine Hindson, “Gratuitous Assistance”?

The West End theatre industry, late-Victorian charity, and patterns of theatrical fundraising',

New Theatre Quarterly 30: 1 (2014), 17-28.

${ }^{33}$ See Richards, Imperialism and Music, 255; 357-8;

${ }^{34}$ Entr'acte, 29 April 1876; Era, 23 April 1876.

${ }^{35}$ Era, 1 October 1892.

${ }^{36}$ Wilhelm's designs are held in collections of the Royal Academy of Dance.

${ }^{37}$ John Plunkett, Queen Victoria: the First Media Monarch (Oxford: Oxford University

Press, 2003), 239-40.

${ }^{38}$ Era, 29 May 1897.

${ }^{39}$ Daily Mail, 26 May 1897.

${ }^{40}$ Pall Mall Gazette, 28 May 1897.

${ }^{41}$ The Times, 26 May 1897.

${ }^{42}$ Daily News, 26 May 1897.

${ }^{43}$ Era, 29 May 1897.

${ }^{44}$ Telegraph, 26 May 1897.

${ }^{45}$ Era, 26 June 1987.

${ }^{46}$ Daily News, 28 June 1897.

47 Daily Mail, 23 June 1897.

${ }^{48}$ Morning Post, 26 June 1897.

${ }^{49}$ Era, 26 June 1897.

${ }^{50}$ Era, 27 February 1897.

${ }^{51}$ Reynolds, 28 February 1897.

${ }^{52}$ Sporting Mirror and Dramatic and Musical Record, 15 March 1897. 
${ }^{53}$ Cited in Richards, Imperialism and Music, 253.

${ }^{54}$ Tori Smith, ““Almost Pathetic ... But Also Very Glorious”: the Consumer Spectacle of the Diamond Jubilee’, Histoire Sociale/Social History 29: 58 (1996), 334-56

${ }^{55}$ The Times, 30 June 1897.

${ }^{56}$ Graphic, 26 June 1897.

${ }^{57}$ Daily Mail, 22 June 1897.

${ }^{58}$ The idea of the 'performing monarchy' has gained ground in recent years - not necessarily the Monarch acting, but, rather, enacting a prescribed role. See Bernd Weisbrod, 'Theatrical Monarchy: the Making of Victoria, the Modern Family Queen’, in Regina Schulte (ed.), The Body of the Queen (Oxford: Berghahn, 2006), 238-53; Jaap van Osta, 'The Emperor’s New Clothes: the Reappearance of the Performing Monarchy, c.1870-1914', in Jeroen Deploige and Gita Deneckere (eds), Mystifying the Monarch: Studies on Discourse, Power and History (Amsterdam: Amsterdam University Press, 2006), 181-92. The provocation for a surge into studies of Victoria as enacting a role was David Cannadine’s, 'The Context, Performance, and Meaning of Ritual: the British Monarchy and the “Invention of Tradition”, c. 1820-1977, in Eric Hobsbawm and Terence Ranger (eds.), The Invention of Tradition (Cambridge: Cambridge University Press, 1983), 101-64.

59 The Daily Mail (Golden Edition), 22 June 1897. For summary, see Jan Morris, Pax Britannica: the Climax of an Empire (London: Faber, 2008), 16-21.

${ }^{60}$ Entr'acte, 5 October 1878.

${ }^{61}$ See Richards, Imperialism and Music, 325-6; Russell, Popular Music, 136-8.

${ }^{62}$ The review also praises choreographer, musical director and scene painter. Era, 6 January 1878.

${ }^{63}$ Era, 7 January 1882, 4 
${ }^{64}$ If space allowed, it would be beneficial to trace the careers of set painters, other ballet masters, and musical directors too. Pritchard, 'Collaborative Creations’, offers a valuable starting point.

${ }^{65}$ Simon Popple, ““Fresh From the Front”: Performance, War News and Popular Culture during the Boer War’, Early Popular Visual Culture 8:4 (2010), 401-18 (at 402-3).

${ }^{66}$ James Ryan, Picturing Empire: photography and the visualisation of the British Empire (Chicago: Chicago University Press, 1997); Kenneth Morgan, ‘The Boer War and the Media', Twentieth Century British History 13:1 (2002), 1-16.

${ }^{67}$ Daily News, 12 December 1899.

${ }^{68}$ Davis, ‘Imperial Transgressions’; Jennifer Schacker, ‘Slaying Blunderboer: Cross-dressed heroes, national identity and wartime pantomime’, Marvels and Tales 27:1 (2013), 52-64. ${ }^{69}$ Several theatres staged pantomime and melodrama throughout the war years that were either set in South Africa or involved troops or others with direct involvement in the conflict. In addition to those mentioned in Jeffrey Richards' chapter, London theatregoers had the option to go to see Sons of Empire (Britannia, 1899), Comrades in Khaki (Garrick, 1899), For Queen and Country (Princess's, 1899), The War Special (Gaiety, 1900) and Fortune of War (St James’s, 1901). See Gould, Nineteenth-Century Theatre, 233 n.2; Jonathan Schneer, London, 1900: The Imperial Metropolis (Yale: Yale University Press, 2001), 95-117.

${ }^{70}$ Both venues reviewed in the Era, 30 December 1899.

${ }^{71}$ Gould, Nineteenth-Century Theatre, 210.

72 Popple, “"Fresh From the Front”', 407-8.

${ }^{73}$ Quoted in Richards, Imperialism and Music, 255.

${ }^{74}$ Era 16 December 1899.

${ }^{75}$ Daily Mail, 12 December 1899. 
${ }^{76}$ Daily News, 12 December 1899; Dramatic World, January 1900, quoted from Schneer, London, 96.

${ }^{77}$ On the 6 January 1900, the Pall Mall Gazette reported that troops, including the officers and non-commissioned officers from the $17^{\text {th }}$ Lancers, were invited to the Empire to enjoy the performance.

${ }^{78}$ Morning Post, 12 December 1899.

${ }^{79}$ Pritchard Collection.

${ }^{80}$ Carter, Dance and Dancers, 20.

${ }^{81}$ The Times review, 10 May 1899 makes special mention of the return of troops of East Africa; so too does the Standard (8 May 1899).

${ }^{82}$ Daily Mail (9 December 1899).

${ }^{83}$ Daily Mail (31 January 1900).

${ }^{84}$ On audiences, see J. Davis and V. Emeljanow, Reflecting the Audience: London theatregoing, 1840-80 (Hatfield: University of Hertfordshire Press, 2001).

${ }^{85}$ Carter, Dance and Dancers, 86; Witchard, 'Bedraggled Ballerinas'.

${ }^{86}$ See Richards, Imperialism and Music, 3-17, for discussion of contemporary approaches to music theory.

${ }^{87}$ Tim Barringer, ‘Sonic Spectacles: The Audio-Visual Nexus, Delhi-London, 1911-12’, in E. Edwards et al (eds), Sensible Objects: Material Culture, the Senses, Colonialism, Museums (London: Berg, 2006), 169-70.

${ }^{88}$ Lynda Nead, Victorian Babylon: People, Streets and Images in Nineteenth-Century London (New Haven, CO: Yale University Press, 2000), 59. See also the special issue of Nineteenth-century Theatre and Film 39:1 (2012) committed to 'Theatre, Art and Visual Culture in the Nineteenth Century' 
${ }^{89}$ M. Meisel, Realizations: Narrative, Pictorial, and Theatrical Arts in Nineteenth-Century England (Princeton: Princeton University Press, 1983),

${ }^{90}$ Ashley Jackson and David Tomkins, Illustrating Empire: a Visual History of British Imperialism (Oxford: 2011); Thomas Richards, The Commodity Culture of Victorian England: Advertising and Spectacle (Stanford: Stanford University Press, 1991); Richard Fulton, ‘The Sudan Sensation’, Victorian Periodicals Review 42:1 (2009), 37-63.

${ }^{91}$ Ziter, The Orient on the Victorian Stage, 188. 